\title{
Confrontative Study between Past Perfect Indicative in German and Past Perfect and Aorist II Indicative in Albanian
}

\author{
Edesa Paheshti \\ PhD-Student, Faculty of Human Sciences, \\ Aleksander Xhuvani University, Elbasan \\ Prof. Dr. Emine Teichmann
}

Tutor

Doi: $10.2478 / m j s s-2018-0068$

\begin{abstract}
The present study represents a significant step forward to understand past perfect indicative in Albanian and German by comparing them in morphological, semantic and stilistic aspects. The semantic meaning of past perfect indicative in Albanian is very similar to that in German. But the Albanian language also alters another additional past tense called Aorist II, that it is not present in the standard German language. This work aims at giving practical and theoretical overview on approaches and differs of the past perfect between the two languages - we intend to show that by giving great argumentative examples, which help concretising and understanding better, and also offer a clear and detailed picture of uses and meanings of this tense in both languages. In particular, in this paper it is paid attention to the text grammar, as we think that is a very important and interested point of view by studying and comparing two grammars. Furthermore we consider the issue of translation from German in Albanian and controversialy. At this point we intend to find the grammar tools the German language uses for the translation of the albanian Aorist II. This publication will be a comprehensive and authorative reference work on complex past tenses bringing together the study on different linguistic aspects.
\end{abstract}

Keywords: Finished event, bitemporal, moment of speaking, temporal indicators

\section{Introduction}

According to the Albanian Academy Grammar $^{1}$ and Duden ${ }^{2}$ indicates past perfect indicative in Albanian and German that an action was completed (finished) at some point in the past before something else happened. This tense has got two obligatory features: Bitemporal and past. ${ }^{3}$ But the Albanian language, morphologically alters a second past tense in indicative called Aorist II - this tense is not present in the standard German language - which meaning is the same to that of past perfect indicative. The past perfect and the Aorist II as well are considered from linguists as synonym tenses - they can easily replace each other. But from both these tenses it is actually the past perfect which is used more frequently in spoken and written language.

\footnotetext{
${ }^{1}$ Albanian Academy of Science, Albanian Institute of Linguistics and Literature - Grammar of the Albanian language 1, Tirana, 2002, page 314.

${ }^{2}$ DUDEN - The Grammar, necessary for correct German 7., new language norm authorities edition, Duden Band 4, Duden Publishing house, Mannheim, 2005, page 518.

${ }^{3}$ O. Buchholz •W. Fiedler - Albanian grammar, Enzyklopädie Leipzig Publishing house, 1987, page 131.
} 


\section{Methodology}

The focus of this paper is based on a theoretical and practical study about the past perfect indicative in Albanian and German, and also the Aorist II indicative in Albanian. The used methodology is a comparing one by studying deeply approaches and differences between these two languages. It has been consulted a large Albanian and German linguistics literature in our interest field. Furthermore the theory has been examined in literature by comparing examples in both languages.

Based on our comparisons, we have listed our points of view and ideas on approaches and differences about the past perfect indicative in Albanian and German, and of course the role of Aorist II indicative.

\section{Background and Purposes}

This paper aims at giving a practical and theoretical overview on approaches and differences about the past perfect indicative between Albanian and German, and also handles Aorist II indicative in Albanian offering a clear and detailed picture of uses and meanings of these tenses in both languages.

We have paid attention to the text grammar and also wish to consider the issue of translation from German in Albanian and controversialy. This publication will be a comprehensive and authorative reference work on past tenses indicative bringing together the study on different linguistic aspects.

\section{Analysis}

Before starting handling the functions of these tenses, we firstly intend to have a look in the morphological level. The past perfect in active voice in Albanian is composed of two parts: „The past tense of the verb ,kam' (to have) in past tense + the past participle of the main verb" [example: unë kisha pyetur (I had asked)]. In the German language the past perfect in active voice is also composed of two parts: "The past tense of the verbs, haben/sein" (to have/to be) in past tense (preterite) + the past participle of the main verb" [examples: ich hatte gefragt/ich war gewesen (I had asked; I had been)]. Based on the morphological formation rules, we have noticed approaches between the two languages in the active voice. In Albanian Aorist II in active voice is also composed of two parts: "The Aorist I of the verb ,kam" (to have) + the past participle of the main verb" (example: unë pata pyetur ${ }^{4}$ ). Above we have mentioned that the German morphologically doesn't alter the Aorist II - so, it is impossible to confront the two grammars in the morphological level about this tense. But we are going to show some very interesting and good argumentative examples by observing them in the translation area. According to Helbig and Buscha ${ }^{5}$, and the Albanian Academy Grammar $^{6}$ the past perfect indicative has got, in both languages, two main variants of use:

1. Past perfect indicating a resultative action in the past (1). This type of past perfect doesn't have any modal factor present, but it can contain facultative temporal indicators or can be followed by a temporal subortinated clause. In this variant the past perfect can be replaced in both languages by perfect.

(1)

Ato kishin qenë plaka në kohën e mbretërisë dhe kishin qenë plaka edhe përpara mbretërisë, në kohën e republikës. (Kronikë në gur, Ismail Kadare, f. 31)

\footnotetext{
${ }^{4}$ It is impossible to translate this example in English as this tense isn't present in the standard English language.

${ }^{5}$ G. Helbig. - J. Buscha - Handbook for the German grammar as a foreign language, Berlin and Mynih: Langescheidt Publishing house, 2005, page 136-137.

${ }^{6}$ Albanian Academy of Science, Albanian Institute of Linguistics and Literature - Grammar of the Albanian language 1, Tirana, 2002, page 314.
} 
Greisinnen waren sie schon während der Königszeit gewesen und auch vorher, in der Republik. (Chronic in Stone, Ismail Kadare, page 38)

In the sentence (1) the moment of speaking is identical to the moment of observing - both took place after the event. The example doesn't contain certain temporal indicators, but we can understand the temporal character of the sentence from the context, and this sentence offers us a very good possibility to observe the summary character of the past perfect: „kohën e mbretërisë, kohën e republikës/ Königszeit, Republik (time of the king, time of the republic) - because they both are cosidering a very long time. And the great thing to observe here is also the connection to the present times - the wise ladies are still the old ones. We can feel here the resultative character of the event in the moment of speaking.

2. Past perfect indicates a completed event in the past, which hasn't got any connection to a certain moment in the past (2). In this variant of use the modal factor is not present - just like in the first one - it can have facultative temporal indicators or can be followed by a temporal subortinated clause.

(2)

Kur dolëm nga shtëpia e Dino Çiços, shiu kishte pushuar. (Kronikë në gur, Ismail Kadare, f. 97) Als wir Dino Çiços Haus verließen, hatte der Regen aufgehört. (Chronic in Stone, Ismail Kadare, Page 112)

The moment the event happened (2) „ka rënë shi/es hat geregnet“ (it has been raining) lays before the observing moment „Kur dolëm nga shtëpia e Dino Çiços /Als wir Dino Çiços Haus verließen“(As we left Dino's house), and both take place before the moment of speaking - the speaker refers later about it. In this variant the past perfect can't be replaced by the perfect. The meaning of the past perfect is precised by the context, just like in the first variant - this tense has got the grammatical value of the Aorist I in the past: The event was completed (finished) before. In Albanian as in German (2) the past perfect is followed by a temporal subordinative clause „Kur dolëm nga shtëpia e Dino Çiços/Als wir Dino Çiços Haus verließen“.

We have mentioned above that the modal factor isn't present in either of the variants of past perfect indicative. And this is very correct as this tense doesn't tend to have modal nuances. According to Buchholz and Fiedler the presence of modal factor in past perfect structures is extremely rare, but not impossible. We could find examples in a main clause of an hypothetical sentence which signals the past perfect unreal conditionality of the past (6). Frequently, it is a preterite comparinson. ${ }^{7}$ (4). Since both applications of the past perfect indicative (3) \& (4) occur in unreal sentences (,pa ia kisha treguar qejfin/sonst hätte er etwas erlebt; sikur kishte parë ndonjë fantazmë/als hätte er einen Geist gesehen") in the translation in German will be applied subjunctive II „kisha treguar:hätte erlebt, kishte parë:hätte gesehen“.

(3)

Ishte yt atë atje, pa ia kisha treguar qejfin!

Es war dein Vater dort, sonst hätte er etwas erlebt.

(4)

Ishte me të vërtetë i hutuar, sikur kishte parë ndonjë fantazmë.

Er sah wirklich verwirt aus, als hätte er einen Geist gesehen.

Furthermore we have noticed, that in both languages, the imperfect, the Aorist I or the preterite indicative turn into past perfect indicative in indirect speech structures (5). In the sentence (5) the cited speaker "Aldo Barabamua" is mentioned - and to report about his words the author

${ }^{7}$ O. Buchholz •W. Fiedler - Albanian grammar, Enzyklopädie Leipzig Publishing house, 1987, page 132. 
has choosen the past perfect in the orginal text in Albanian, and also in the translation in German. In both cases in the first part of the sentence - the quoted speech - the verbs are used to report what originally was said: They are in preterite "gab" in German and in Aorist I "kishte“ in Albanian.

(5)

- Eh, artileri kishte në kohën time, - kishte thënë duke ngritur gotën e fundit në kafene Avdo Barabamua. (Kronikë në gur, Ismail Kadare, f. 98)

„Ja, zu meiner Zeit, da gab es noch Artillerie!" hatte Avdo Babaramo, das letzte Glas erhebend, im Café erklärt. (Chronic in Stone, Ismail Kadare, Page 113)

In both from us choosen novels lead preterite in German and imperfect in Albanian as narrative tenses. When the writers want to refer about an event that had happened before a certain moment in the past, so before imperfect, they do use the past perfect. This is generally the case, and there may also be examples in which the author decides more on the preterite in German, and in the translation in Albanian, even in the original text is applied the past perfect - this can be explained very well by considering the inclination of the Albanian language to use the past perfect indicative, when it comes to describe events or characters in the past. In German, preterite is preferred as narrative tense, and when we compare the spectrum of using this tense in German to that in Albanian, we come to the conclusion: The application spectrum of the preterite as a narrative tense in German is wider as in Albanian. Below we can observe the confrontation „past perfect in Albanian : preterite in German" through the example (6) taken from the author I. Kadare in Albanian and translated in German by J. Röhm.

(6)

Pastaj gruaja e kish spërkatur vendin dhe kish ikur shpejt duke ua humbur gjurmët atyre që e ndoqën. (Kronikë në gur, Ismail Kadare, f. 27)

Dann hatte die Frau den Ort besprengt und war so rasch verschwunden, dass die Verfolger ihrer Spur verloren. (Chronic in Stone, Ismail Kadare, Page 33)

Another important focus of our work is the issue of translation. If we look closer at above mentioned examples $(1-6)$, we can say that in the translation area, both languages almost act the same: We identified approaches in the semantic, syntax, emotional, stylistic and modal levels.

At the beginning of this work, we have mentioned, that the morphological forms of the Aorist II indicative are not present in German - by translating Aorist II from the Albanian into German, translators use the past perfect indicative (7) \& (8). Let us have a look at the examples below, taken from the novel "Chronic in Stone" by Ismail Kadare, and the novel "Nothing new from the Western front" by Erich Maria Remark (7) \& (8), and understand better which tense the translaters have choosen to translate the Aorist II in German:

(7)

Er war nur bewusstlos gewesen. (Im Westen nichts Neues, Erich Maria Remarque, Page 16)

Pati qenë pa ndjenja për një kohë të gjatë. (Asgjë e re nga fronti i perëndimit, Erik Maria Remark, f. 18)

(8)

Gruaja e Mane Vocos qe zbardhur në fytyrë nga tmerri. E panjohura qe zhdukur sa të hapësh e mbyllësh sytë. (Kronikë në gur, Ismail Kadare, f. 27, 28)

Mane Vocos Frau war schreckenbleich geworden. Keinen Wimpernschlag später war die Fremde verschwunden gewesen. (Chronic in Stone, Ismail Kadare, Page 33)

As Aorist II indicative in Albanian has the same meaning to the past perfect indicative also in Albanian, may this lead the translators to use the same tense structure as past perfect, when it 
comes to translate structures of Aorist II from Albanian to German or controversily. In the examples (7) and (8) in German, the verbs „war gewesen“ and „war geworden“ are in past perfect indicative. Sentence (7) is taken from the original text in German and the translator has decided to use Aorit II in Albanian „pati qenë“. The same happens when we observe the translation from Albanian into German in the example (8): The translator used the past perfect in German for the sentences in Aorist II in Albanian „qe zbardhur" and "“qe zhdukur". Therefore, both these tenses „Aorist II:Past perfect" can be treated morphogically and semantically as synonyms, so they can easily replace each other and this doesn't affect the meaning of the sentence at all.

\section{Conclusions and Recommandations}

Both languages alter the past perfect indicative - it indicates that an action was completed (finished) at some point in the past before something else happened. The past perfect has got two obligatory features: Bitemporal and past. Based on the grammatical structure, there are also morphological approaches between German and Albanian.

Temporal factor occupies a large place and there is almost no space for the modal one. Temporal indicators appear facultative in past perfective uses or the sentense is accompanied from a temporal subordinate clause. Examples of past perfect wich have modal factor present may appear in the main clause of a hypothetical sentence, where the past pefect indicates unreal past conditionality - these structures in German are given by conjunctive II.

Semantic uses oft past perfect tense in both languages are similar - in Albanian as in German we distinguish two important variants of use.

The Albanian morphologically alters also a tense, the Aorist II - but the grammatical category of Aorist II indicative isn't found in the German language. So, it's impossible to make a morphological comparision between Albanian and German about that. Meaning and uses of Aorist II indicative in Albanian are similar to the past perfect indicative. In the translations of the Albanian Aorist II indicative into German is this tense given by the past pefect indicative.

In the translation area, both languages almost act the same: When we do translate past perfect indicative sentences from Albanian into German or controversaly, we identify approaches in the semantic, syntax, emotional, stylistic and modal levels.

\section{Acknowledgements}

We thank Prof. Dr. Emine Teichmann for her supervision of the current study. In addition, we thank our family for the great support.

\section{References}

Buchholz, Oda • Fiedler, Wilfried (1987), Albanische Grammatik Verlag Enzyklopädie Leipzig.

Teichmann, Emine (2015), Handbuch Grammatik der albanischen Sprache Teil I, GRIN Verlag, Deutschland.

Teichmann, Emine et al. (2015), Grammatisches Wörterbuch für Albanisch. Eine grammatisch-lexikographische Zusammenstellung, GRIN Verlag, Deutschland.

Harald, Weinrich (1993), Textgrammatik der deutschen Sprache, Dudenverlag, Deutschland.

Helbig, Gerhardt - Buscha, Joachim (2001), Deutsche Grammatik, ein Handbuch für Ausländerunterricht, Langenscheidt, Berlin und München, Deutschland.

DUDEN - Die Grammatik, Unentbehrlich für richtiges Deutsch 7., völlig neu erarbeitete und erweiterte Auflage, (2005), Duden Band 4, Dudenverlag, Mannheim, Deutschland.

DUDEN Grammatik der deutschen Gegenwartssprache, (2003), Duden Band 4, Mannheim, Leipzig, Wien, Zürich.

Akademia e Shkencave e Shqipërisë, Instituti i Gjuhësisë dhe i Letërsisë (2002), Gramatika e gjuhës shqipe, Tiranë,

Demiraj, Shaban (1970), Morfologji e gjuhës së sotme shqipe, II, Tiranë.

Agalliu, Fatmir (1988), Çështje të morfologjisë së gjuhës së sotme shqipe, Tiranë.

Demiraj, Shaban (1976), Morfologjia historike e gjuhës shqipe, II, Tiranë.

Morina, Vjosa (2009), Masterarbeit Modus und Tempus im Deutschen und Albanischen, Wien. 